\title{
Bio-Based Bisbenzoxazines with Flame Retardant Linker
}

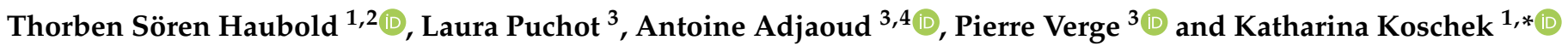 \\ 1 Fraunhofer Institute for Manufacturing Technology and Advanced Materials IFAM, Wiener Strasse 12, \\ 28359 Bremen, Germany; Thorben.haubold@ifam.fraunhofer.de \\ 2 Department 2 Biology/Chemistry, University of Bremen, Leobener Straße 7, 28359 Bremen, Germany \\ 3 Materials Research and Technology Department, Luxembourg Institute of Science and Technology, \\ 5 Avenue des Hauts-Fourneaux, L-4362 Esch-sur-Alzette, Luxembourg; laura.puchot@list.lu (L.P.); \\ Antoine.adjaoud@list.lu (A.A.); pierre.verge@list.lu (P.V.) \\ 4 Department of Physics and Materials Science, University of Luxembourg, 2, Avenue de l'Université, \\ L-4365 Esch-sur-Alzette, Luxembourg \\ * Correspondence: katharina.koschek@ifam.fraunhofer.de
}

Citation: Haubold, T.S.; Puchot, L.; Adjaoud, A.; Verge, P.; Koschek, K. Bio-Based Bisbenzoxazines with Flame Retardant Linker. Polymers 2021, 13, 4330. https://doi.org/ $10.3390 /$ polym 13244330

Academic Editor: Pablo Froimowicz

Received: 7 October 2021

Accepted: 7 December 2021

Published: 10 December 2021

Publisher's Note: MDPI stays neutral with regard to jurisdictional claims in published maps and institutional affiliations.

Copyright: (c) 2021 by the authors. Licensee MDPI, Basel, Switzerland. This article is an open access article distributed under the terms and conditions of the Creative Commons Attribution (CC BY) license (https:// creativecommons.org/licenses/by/ $4.0 /)$.
Abstract: This work explores the strategy of incorporating a highly substituted reactive flame retardant into a benzoxazine moiety. For this purpose, a DOPO-based flame retardant received a chain extension via reaction with ethylene carbonate. It was then reacted with phloretic acid to obtain a diphenol end-capped molecule, and further reacted with furfurylamine and paraformaldehyde to obtain a benzoxazine monomer via a Mannich-like ring closure reaction. This four-step synthesis yielded a partly bio-based halogen-free flame retardant benzoxazine monomer (DOPO-PA-fa). The successful synthesis was proven via NMR, IR and MS analysis. The polymerization behavior was monitored by DSC and rheological analysis both showing the polymerization starts at $200{ }^{\circ} \mathrm{C}$ to yield pDOPO-PA-fa. pDOPO-PA-fa has a significant thermal stability with a residual mass of $30 \%$ at $800{ }^{\circ} \mathrm{C}$ under ambient atmosphere. Furthermore, it reached a V-0 rating against small flames and an OI of $35 \%$. Blended with other benzoxazines, it significantly improves their thermal stability and fire resistance. It emphasizes its potential as flame retardant agent.

Keywords: flame retardancy; benzoxazine; halogen-free; bio-based

\section{Introduction}

Polybenzoxazines are thermosetting materials with excellent properties, such as a near-zero shrinkage upon polymerization [1], high mechanical and thermal properties [2]. They have gained a lot of attention during the last decade since many different bio-sourced synthons can be used to design their molecular structure, which simply require a primary amine, a phenol non-substituted in ortho position and an aldehyde. For instance, furfurylamine [3], stearylamine [4], chitosan [5] and amines, based on rosin [6], isomannide [7] and vanilin [8] have been employed as amines; additionally, guaiacol [4,9], sesamol [10,11], cardanol $[7,12,13]$, eugenol [14] or phloretic acid (PA) $[15,16]$ have been used as naturally occurring phenolic compounds. The design of formaldehyde-free monomers is now hyping, with the recent works of Caillol et al. [17,18], and Ishida and Froimowicz et al. [11].

Even if benzoxazines exhibit a naturally good intrinsic flame retardancy, the demand to increase their fire properties is significant enough to have initiated many research studies. The flame retardancy (FR) of polymers can be improved by different approaches: the use of unreactive [19] or reactive additives [20], and the incorporation of flame retardant groups into the monomer structure [21]. Among the flame retardant groups, 9,10-dihydro-9-oxa10-phosphaphenanthrene-10-oxide (DOPO) is a widely investigated halogen-free reactive additive that is mainly gas phase active yielding $\mathrm{PO}$ and HPO radicals upon decomposition. It has the advantage to trap energetic radicals and to improve the reaction against small flames [22]. DOPO is an efficient FR as additive or chemically incorporated in a 
molecular structure, e.g., epoxies [23,24] or polyester [25-27]. DOPO derivatives, e.g., dopotriamine [21] or dopotriol [28], were incorporated into benzoxazine to improve its flame retardancy. Partly bio-based bisbenzoxazines were described by combining DOPO with bio-based bisphenols and the following reaction with furfurylamine and paraformaldehyde [29]. Furthermore, DOPO can be incorporated into the oxazine ring at the 4-position during the ring closing reaction. For this purpose, DOPO reacts with phenol benzaldehyde and different amine functionalities, e.g., tolyl-, $p$-hydroxyphenyl-, $p$-carboxyphenyl- [30], aniline- [31] or diamines-based functionalities [32]. The high aromaticity and the resulting highly ordered structures due to pi-stacking lead to high melting temperatures. This results in a narrow temperature range between melting and polymerization temperature, which impedes the polymerization process of these monomers.

This contribution describes the synthesis and testing of a new bio-based benzoxazine, which is easy to polymerize and has high flame retardancy, in regards to tests against small flames. This was accomplished by the functionalization of DOPO with a phenolic spacer, further functionalized into a benzoxazine. The DOPO linker aims at improving flame retardancy without increasing the melting temperature of the resulting bisbenzoxazine. The linker synthesis was started from the reaction between DOPO and benzoquinone, leading to DOPO-HQ, and followed by a chain extension by reacting DOPO-HQ with ethylene carbonate leading to $\mathrm{DOPO}-\mathrm{OH}$, as previously reported by Wang et al. (Scheme 1) [26]. DOPO-OH was thus reacted with phloretic acid to yield DOPO-PA, following a procedure previously reported $[15,33,34]$. The resulting bisphenolic DOPO linker was finally reacted with furfurylamine and paraformaldehyde to yield the benzoxazine monomer DOPO-PA-fa. The contribution reports on the synthetic steps to achieve the DOPO functionalized bio-based bisbenzoxazine. The novel monomer was then investigated by thermo-analytical methods and rheology in order to describe the polymerization behavior. The thermo-dynamic mechanical stability and reaction against small flames of the resulting polybenzoxazines is also reported in this contribution.

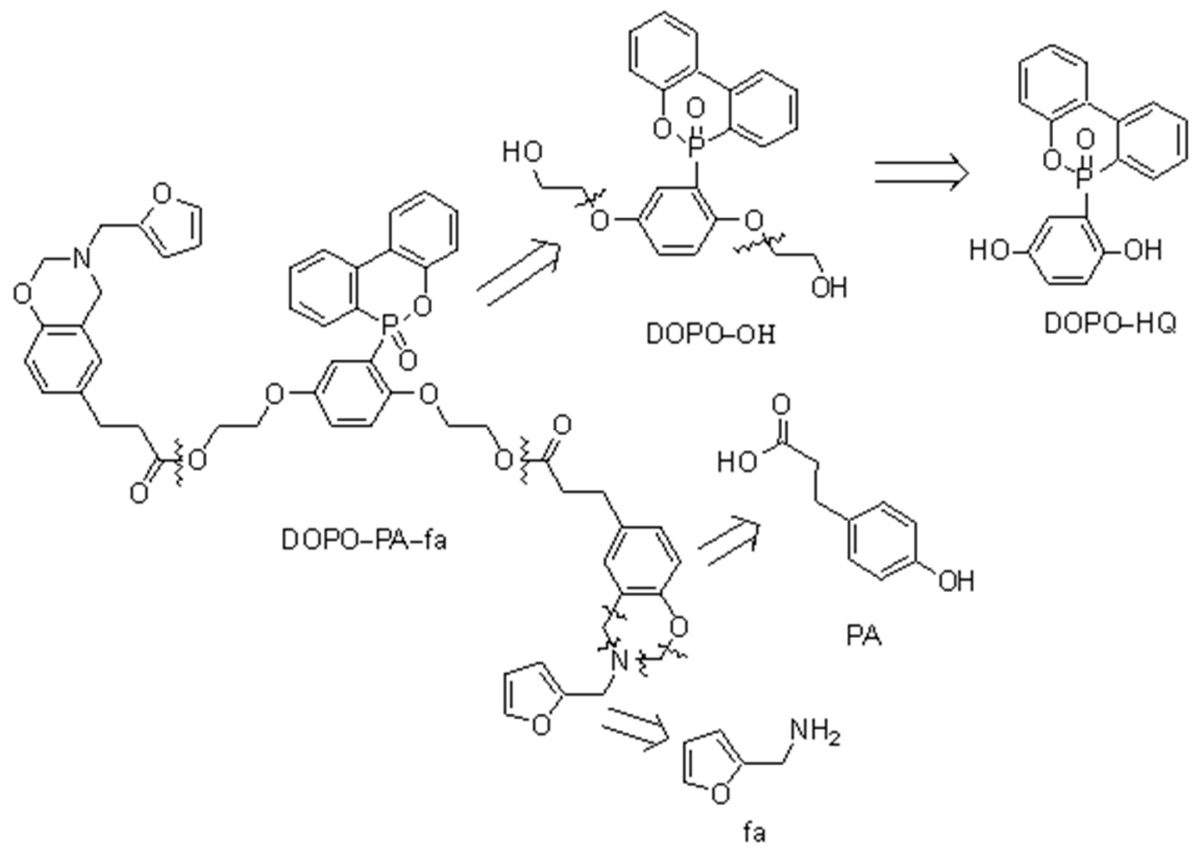

Scheme 1. Building blocks for the synthesis of DOPO-PA-fa.

2. Materials and Methods

2.1. Materials and Reagents

2-Ethoxyethanol, $p$-benzoquinone, dimethylacetamide, ethylene carbonate, 2-propanol, phloretic acid, $p$-toluene sulfonic acid monohydrate, paraformaldehyde, furfurylamine, DOPO, potassium iodide, chloroform and ethyl acetate were supplied from Sigma-Aldrich 
(Taufkirchen, Germany) and DOPO from TCI (Zwijndrecht, Belgium). All chemicals were used without further purification.

\subsection{Synthesis}

2.2.1. Synthesis of 2-(6-Oxido-6H-dibenz(c,e)(1,2)oxaphosphorin-6-yl)-1,4-hydroxy Phenylene (DOPO-HQ)

The synthesis of DOPO-HQ was adapted by Wang et al. [27]. DOPO (5.40 g, $25 \mathrm{mmol}$, 1 eq.) was dissolved in 2-ethoxyethanol $(20 \mathrm{~mL})$ at $90^{\circ} \mathrm{C}$. After complete solvation, benzoquinone $(2.45 \mathrm{~g}, 22.5 \mathrm{mmol}, 0.9 \mathrm{eq}$.) was slowly portion wise added as a powder, and the reaction mixture was heated to $125{ }^{\circ} \mathrm{C}$ for $4 \mathrm{~h}$. After cooling to room temperature, the mixture was filtered, and the powder was recrystallized from 2-ethoxyethanol. The product was dried under reduced pressure at $90{ }^{\circ} \mathrm{C}$ for $12 \mathrm{~h}$ to obtain an off-white powder in a $73 \%$ yield.

${ }^{1} \mathrm{H}$ NMR $\left(\right.$ DMSO-d $\left.\mathrm{d}_{6}, 600 \mathrm{MHz}, 298 \mathrm{~K}\right): \delta(\mathrm{ppm})=($ assignment, multiplicity, \{attribution\}, experimental integration, theoretical integration). $\delta=9.46\left(\mathrm{Ar}^{-\mathrm{OH}^{*}}, \mathrm{~s},\{\mathrm{a}\}, \exp 1.00 \mathrm{H}\right.$, th $1.00 \mathrm{H}) ; 9.17\left(\mathrm{Ar}^{-O \mathrm{OH}^{*}}, \mathrm{~s},\{\mathrm{~b}\}, \exp 1.00 \mathrm{H}\right.$, th $\left.1.00 \mathrm{H}\right) ; 8.27-8.20\left(\mathrm{Ar}-\mathrm{H}^{*}, \mathrm{~m},\{8,15\}, \exp 2.08 \mathrm{H}\right.$, th $2.00 \mathrm{H}) ; 7.74\left(\mathrm{Ar}-\mathrm{H}^{*}, \mathrm{t},\{9\}, \exp 1.03 \mathrm{H}\right.$, th $\left.1.00 \mathrm{H}\right) ; 7.55-7.62\left(\mathrm{Ar}-\mathrm{H}^{*}, \mathrm{dd},\{11\}, \exp 1.08 \mathrm{H}\right.$, th $1.00 \mathrm{H}) ; 7.50\left(\mathrm{Ar}-\mathrm{H}^{*}, \mathrm{td},\{10\}, \exp 1.07 \mathrm{H}\right.$, th $\left.1.00 \mathrm{H}\right) ; 7.45\left(\mathrm{Ar}-\mathrm{H}^{*}, \mathrm{t},\{17\}, \exp 1.04 \mathrm{H}\right.$, th $1.00 \mathrm{H}) ; 7.32-7.26\left(\mathrm{Ar}-\mathrm{H}^{*}, \mathrm{~m},\{16,18\}, \exp 2.06 \mathrm{H}\right.$, th $\left.2.00 \mathrm{H}\right) ; 7.19\left(\mathrm{Ar}^{-} \mathrm{CH}^{*}, \mathrm{dd},\{2\}, \exp 1.02 \mathrm{H}\right.$, th $1.00 \mathrm{H}) ; 6.89\left(\mathrm{Ar}-\mathrm{H}^{*}, \mathrm{dd},\{4\}, \exp 1.03 \mathrm{H}\right.$, th $\left.1.00 \mathrm{H}\right) ; 6.64\left(\mathrm{Ar}-\mathrm{H}^{*}, \mathrm{dd},\{5\}, \exp 1.03 \mathrm{H}\right.$, th $1.00 \mathrm{H}) \mathrm{ppm}$.

${ }^{31} \mathrm{P}$ NMR $\left(243 \mathrm{MHz}, \mathrm{DMSO}_{6}, 298 \mathrm{~K}\right) \delta=22.11$ (s) ppm.

2.2.2. 2-(6-Oxido-6H-dibenz(c,e)(1,2)oxaphosphorin-6-yl)-1,4-hydroxyethoxy Phenylene (DOPO-OH)

The synthesis of DOPO-OH was adapted by Wang et al. [27]. Dimethylacetamide $(100 \mathrm{~mL})$ was poured in a two-neck flask with reflux condenser and nitrogen inlet. Ethylene carbonate ( $24.44 \mathrm{~g}, 277.5 \mathrm{mmol}, 3 \mathrm{eq}$.), DOPO-HQ ( $30.00 \mathrm{~g}, 92.5 \mathrm{mmol}, 1 \mathrm{eq}$.) and potassium iodide ( $394 \mathrm{mg}, 2.4 \mathrm{mmol}, 0.03 \mathrm{eq}$.) were added. The mixture was heated and stirred at $160^{\circ} \mathrm{C}$ for $7 \mathrm{~h}$. After that time, the crude product was precipitated by pouring the solution into water $(600 \mathrm{~mL})$. A formed gum was stirred with spatula. After $3 \mathrm{~h}$ the gum turned into a solid precipitate which was filtered. The crude product was recrystallized from 2-propanol, filtered and dried at $90{ }^{\circ} \mathrm{C}$ under reduced pressure for $14 \mathrm{~h}$. DOPO-OH was obtained as off-white powder in a yield of $62 \%$.

${ }^{1} \mathrm{H}$ NMR (DMSO-d $\left.6,600 \mathrm{MHz}, 298 \mathrm{~K}\right): \delta(\mathrm{ppm})=($ assignment, multiplicity, \{attribution\}, experimental integration, theoretical integration). $\delta=8.29-8.21\left(\mathrm{Ar}-\mathrm{H}^{*}, \mathrm{~m},\{8,15\}\right.$, exp $2.4 \mathrm{H}$, th $2.00 \mathrm{H}) ; 7.76\left(\mathrm{Ar}-\mathrm{H}^{*}, \mathrm{t},\{9\}\right.$, exp $0.56 \mathrm{H}$, th $\left.1.00 \mathrm{H}\right) ; 7.71-7.65\left(\mathrm{Ar}-\mathrm{H}^{*}, \mathrm{dd},\{11\}\right.$, exp $0.81 \mathrm{H}$, th $1.00 \mathrm{H}) ; 7.52\left(\mathrm{Ar}-\mathrm{H}^{*}, \mathrm{td},\{10\}, \exp 1.48 \mathrm{H}\right.$, th $\left.1.00 \mathrm{H}\right) ; 7.46\left(\mathrm{Ar}-\mathrm{H}^{*}, \mathrm{t},\{17\}, \exp 1.17 \mathrm{H}\right.$, th $1.00 \mathrm{H}) ; 7.36\left(\mathrm{Ar}-\mathrm{H}^{*}, \mathrm{dd},\{16\}, \exp 0.94 \mathrm{H}\right.$, th $\left.1.00 \mathrm{H}\right) ; 7.33-7.29\left(\mathrm{Ar}^{-} \mathrm{CH}^{*}, \mathrm{~m},\{18,2\}, \exp \right.$ $1.66 \mathrm{H}$, th $2.00 \mathrm{H}) ; 7.20\left(\mathrm{Ar}-\mathrm{H}^{*}, \mathrm{dd},\{4\}, \exp 0.81 \mathrm{H}\right.$, th $\left.1.00 \mathrm{H}\right) ; 7.03\left(\mathrm{Ar}-\mathrm{H}^{*}, \mathrm{dd},\{5\}, \exp 1.00 \mathrm{H}\right.$, th $1.00 \mathrm{H}) ; 4.87\left(\mathrm{CH}_{2}-\mathrm{OH}^{*}, \mathrm{t},\{\mathrm{a}\}, \exp 0.85 \mathrm{H}\right.$, th $\left.1.00 \mathrm{H}\right) ; 4.46\left(\mathrm{CH}_{2}-\mathrm{OH}^{*}, \mathrm{t},\{\mathrm{b}\}, \exp 0.86 \mathrm{H}\right.$, th $1.00 \mathrm{H}) ; 4.03-3.91\left(\mathrm{Ar}-\mathrm{O}-\mathrm{CH}_{2}{ }^{*}, \mathrm{~m},\{19\}\right.$, exp $1.39 \mathrm{H}$, th $\left.2.00 \mathrm{H}\right) ; 3.72-3.67\left(\mathrm{CH}_{2}{ }^{*}, \mathrm{~m},\{20,21\}\right.$, exp $2.56 \mathrm{H}$, th $3.00 \mathrm{H}), 3.59-3.52\left(\mathrm{Ar}-\mathrm{O}-\mathrm{CH}_{2}{ }^{*}, \mathrm{~m},\{21\}, \exp 0.82 \mathrm{H}\right.$, th $\left.1.00 \mathrm{H}\right) ; 2.98-2.93\left(\mathrm{HO}_{-} \mathrm{CH}_{2}{ }^{*}\right.$, $\mathrm{m},\{19\}, \exp 1.49 \mathrm{H}$, th $2.00 \mathrm{H}) \mathrm{ppm}$.

${ }^{31} \mathrm{P}$ NMR $\left(243 \mathrm{MHz}, \mathrm{DMSO}_{6}, 298 \mathrm{~K}\right) \delta=22.11$ (s) ppm.

\subsubsection{DOPO-PA}

The solventless method was adapted from previous reports [29]. Phloretic acid ( $26.51 \mathrm{~g}, 159.5 \mathrm{mmol}, 2.2 \mathrm{eq}$.) was melted in a round-bottom flask at $130{ }^{\circ} \mathrm{C}$. On complete melting, DOPO-OH ( $29.90 \mathrm{~g}, 72,5 \mathrm{mmol}, 1$ eq. $)$ was added portion wise before $p$-toluene sulfonic acid monohydrate $(0.70 \mathrm{~g}, 3.6 \mathrm{mmol}, 0.05$ eq.) was added. The melt was stirred for $20 \mathrm{~h}$. The glassy product was recrystallized from ethyl acetate to obtain a white powder in a $67 \%$ yield.

${ }^{1} \mathrm{H}$ NMR (DMSO-d 6 , $\left.600 \mathrm{MHz}, 298 \mathrm{~K}\right): \delta(\mathrm{ppm})=$ (assignment, multiplicity, \{attribution\}, experimental integration, theoretical integration). $\delta=9.16\left(\mathrm{Ar}_{2}-\mathrm{OH}^{*}, \mathrm{t},\{\mathrm{a}, \mathrm{b}\}, \exp \right.$ 
$1.86 \mathrm{H}$, th $2.00 \mathrm{H}) ; 8.21-8.13\left(\mathrm{Ar}-\mathrm{H}^{*}, \mathrm{~m},\{8,15\}, \exp 2.02 \mathrm{H}\right.$, th $\left.2.00 \mathrm{H}\right) ; 7.74-7.69\left(\mathrm{Ar}-\mathrm{H}^{*}, \mathrm{t},\{9\}\right.$, $\exp 0.56 \mathrm{H}$, th $1.00 \mathrm{H}) ; 7.58-7.50\left(\mathrm{Ar}-\mathrm{H}^{*}, \mathrm{~m},\{11,10\}, \exp 1.92 \mathrm{H}\right.$, th $\left.2.00 \mathrm{H}\right) ; 7.45\left(\mathrm{Ar}-\mathrm{H}^{*}, \mathrm{t}\right.$, $\{17\}, \exp 1.07 \mathrm{H}$, th $1.00 \mathrm{H}) ; 7.39\left(\mathrm{Ar}-\mathrm{H}^{*}, \mathrm{t},\{16\}, \exp 1.01 \mathrm{H}\right.$, th $\left.1.00 \mathrm{H}\right) ; 7.28-7.21\left(\mathrm{Ar}^{-\mathrm{CH}^{*}}, \mathrm{~m}\right.$, $\{2,4,18\}, \exp 1.66 \mathrm{H}$, th $2.00 \mathrm{H}) ; 7.03-6.96\left(\mathrm{Ar}-\mathrm{H}^{*}, \mathrm{~m},\{5,35,40\}, \exp 2.97 \mathrm{H}\right.$, th $\left.3.00 \mathrm{H}\right) ; 6.94-6.91$ $\left(\mathrm{Ar}-\mathrm{H}^{*}, \mathrm{dt},\{25,29\}, \exp 2.07 \mathrm{H}\right.$, th $\left.2.00 \mathrm{H}\right) ; 6.67-6.63\left(\mathrm{Ar}-\mathrm{H}^{*}, \mathrm{dt},\{26,28,37,39\}, \exp 3.83 \mathrm{H}\right.$, th $4.00 \mathrm{H}) ; 4.35\left(\mathrm{CH}_{2}-\mathrm{CH}_{2}{ }^{*}, \mathrm{t},\{20\}\right.$, exp $1.88 \mathrm{H}$, th $\left.2.00 \mathrm{H}\right) ; 4.25-4.16\left(\mathrm{CH}_{2}-\mathrm{CH}_{2}{ }^{*}, \mathrm{~m},\{19\}\right.$, exp $1.73 \mathrm{H}$, th $2.00 \mathrm{H}) ; 3.87-3.80\left(\mathrm{Ar}-\mathrm{O}-\mathrm{CH}_{2}{ }^{*}, \mathrm{~m},\{30\}, \exp 1.01 \mathrm{H}\right.$, th $\left.1.00 \mathrm{H}\right) ; 3.71-3.66\left(\mathrm{Ar}-\mathrm{O}-\mathrm{CH}_{2}{ }^{*}\right.$, $\mathrm{m},\{30\}, \exp 0.97 \mathrm{H}$, th $1.00 \mathrm{H}) ; 3.49-3.42\left(\mathrm{Ar}-\mathrm{O}-\mathrm{CH}_{2}{ }^{*}, \mathrm{~m},\{31\}, \exp 0.99 \mathrm{H}\right.$, th $\left.1.00 \mathrm{H}\right) ; 3.39-3.35$ (Ar-O- $\mathrm{CH}_{2}{ }^{*}, \mathrm{~m},\{31\}, \exp 0.48 \mathrm{H}$, th $\left.1.00 \mathrm{H}\right) ; 2.75\left(\mathrm{O}=\mathrm{C}_{-} \mathrm{CH}_{2}-\mathrm{CH}_{2}{ }^{*}, \mathrm{t},\{23\}, \exp 1.86 \mathrm{H}\right.$, th

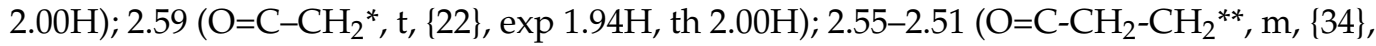
$\exp 1.50 \mathrm{H}$, th $2.00 \mathrm{H}) ; 2.24-2.02\left(\mathrm{O}=\mathrm{C}-\mathrm{CH}_{2}{ }^{* *}, \mathrm{~m},\{33\}\right.$, exp $1.59 \mathrm{H}$, th $\left.2.00 \mathrm{H}\right) \mathrm{ppm}$

${ }^{31} \mathrm{P}$ NMR $\left(243 \mathrm{MHz}, \mathrm{DMSO}_{6}, 298 \mathrm{~K}\right) \delta=21.70$ (s) ppm.

MS (ESI) $m / z,[\mathrm{M}+\mathrm{Na}]^{+}$calculated for $\mathrm{C}_{40} \mathrm{H}_{37} \mathrm{NaO}_{10} \mathrm{P}^{+}, 731.20165$; found, 731.20080.

\subsubsection{DOPO-PA-fa}

Furfurylamine (5.74 g, $59.1 \mathrm{mmol}, 2.05$ eq.) was mixed with paraformaldehyde ( $2.04 \mathrm{~g}$, $67.8 \mathrm{mmol}, 2.35$ eq.) in chloroform $(70 \mathrm{~mL})$ and heated to $65^{\circ} \mathrm{C}$ for $1 \mathrm{~h}$ before the addition of DOPO-PA (20.43 g, $28.83 \mathrm{mmol}, 1 \mathrm{eq}$.), paraformaldehyde ( $2.04 \mathrm{~g}, 67.8 \mathrm{mmol}, 2.35 \mathrm{eq}$.) and chloroform $(100 \mathrm{~mL})$. The reaction mixture was heated at $65^{\circ} \mathrm{C}$ for $48 \mathrm{~h}$. The reaction solution was added to a separation funnel and the organic layer was washed twice with aqueous hydrochloric acid $(0.5 \mathrm{M})$, deionized water, saturated sodium carbonate and brine. The organic layer was pre-dried with magnesium sulfate and filtered, before the chloroform was removed under reduced pressure and the oil was further dried for $14 \mathrm{~h}$ at $50{ }^{\circ} \mathrm{C}$. The product was obtained as yellow oil in a yield of $71 \%$.

${ }^{1} \mathrm{H}$ NMR $($ DMSO-d $6,600 \mathrm{MHz}, 298 \mathrm{~K}): \delta(\mathrm{ppm})=($ assignment, multiplicity, \{attribution\}, experimental integration, theoretical integration). $\delta=8.21-8.14\left(\mathrm{Ar}-\mathrm{H}^{*}, \mathrm{~m},\{8,15\}\right.$, exp $2.02 \mathrm{H}$, th $2.00 \mathrm{H}) ; 7.71\left(\mathrm{Ar}-\mathrm{H}^{*}, \mathrm{t},\{9\}\right.$, exp $0.56 \mathrm{H}$, th $\left.1.00 \mathrm{H}\right) ; 7.60\left(\mathrm{fu}^{-\mathrm{CH}^{*}}, \mathrm{dd},\{36,53\}\right.$, exp $1.37 \mathrm{H}$, th $2.00 \mathrm{H}) ; 7.56-7.50\left(\mathrm{Ar}-\mathrm{H}^{*}, \mathrm{~m},\{11,10\}, \exp 1.73 \mathrm{H}\right.$, th $\left.2.00 \mathrm{H}\right) ; 7.47-7.42\left(\mathrm{Ar}-\mathrm{H}^{*}, \mathrm{~m}\right.$, $\{17\}, \exp 0.97 \mathrm{H}$, th $1.00 \mathrm{H}) ; 7.38\left(\mathrm{Ar}-\mathrm{CH}^{*}, \mathrm{t},\{16\}, \exp 1.00 \mathrm{H}\right.$, th $\left.1.00 \mathrm{H}\right) ; 7.28-7.21\left(\mathrm{Ar}-\mathrm{CH}^{*}\right.$, $\mathrm{m},\{2,4,18\}, \exp 2.93 \mathrm{H}$, th $3.00 \mathrm{H}) ; 7.04-6.87\left(\mathrm{Ar}-\mathrm{H}^{*}, \mathrm{~m},\{5,25,43\}\right.$, exp $1.84 \mathrm{H}$, th $\left.3.00 \mathrm{H}\right) ; 6.87$ $\left(\mathrm{Ar}-\mathrm{H}^{*}, \mathrm{~s},\{40,47\}, \exp 1.13\right.$, th $\left.1.00 \mathrm{H}\right) ; 6.76\left(\mathrm{Ar}-\mathrm{H}^{*}, \mathrm{~s},\{29\}\right.$, exp 0.74, th $\left.1.00 \mathrm{H}\right) ; 6.68-6.62$ $\left(\mathrm{Ar}-\mathrm{H}^{*}, \mathrm{dt},\{44,26\}, \exp 2.12 \mathrm{H}\right.$, th $\left.2.00 \mathrm{H}\right) ; 6.44-6.38\left(\mathrm{fu}-\mathrm{CH}^{*}, \mathrm{~m},\{35,52\}, \exp 1.63 \mathrm{H}\right.$, th $2.00 \mathrm{H}) ; 6.32-6.25$ (fu-CH ${ }^{*}, \mathrm{~m},\{34,51\}, \exp 1.45 \mathrm{H}$, th $\left.2.00 \mathrm{H}\right) ; 4.77\left(\mathrm{O}-\mathrm{CH}_{2}{ }^{*} \mathrm{~N}, \mathrm{~d},\{31,49\}\right.$, exp $2.75 \mathrm{H}$, th $4.00 \mathrm{H}) ; 4.41-4.31\left(\mathrm{CH}_{2}-\mathrm{CH}_{2}{ }^{*}, \mathrm{~m},\{20\}, \exp 1.84 \mathrm{H}\right.$, th $\left.2.00 \mathrm{H}\right) ; 4.26-4.16\left(\mathrm{CH}_{2}-\mathrm{CH}_{2}{ }^{*}\right.$, $\mathrm{m},\{19\}, \exp 1.23 \mathrm{H}$, th $2.00 \mathrm{H}) ; 3.88-3.82\left(\mathrm{CH}_{2}-\mathrm{CH}_{2}{ }^{*}, \mathrm{~N}-\mathrm{CH}_{2}{ }^{*}-\mathrm{Ar}, \mathrm{t},\{30,37,48\}, \exp 3.45 \mathrm{H}\right.$, th $5.00 \mathrm{H}) ; 3.80\left({\mathrm{~N}-\mathrm{CH}_{2}}^{*}, \mathrm{c},\{32,50\}, \exp 2.91 \mathrm{H}\right.$, th $\left.4.00 \mathrm{H}\right) ; 3.87-3.80\left(\mathrm{Ar}-\mathrm{O}-\mathrm{CH}_{2}{ }^{*}, \mathrm{~m},\{37\}, \exp \right.$ $1.01 \mathrm{H}$, th $1.00 \mathrm{H}) ; 3.71-3.66\left(\mathrm{Ar}-\mathrm{O}-\mathrm{CH}_{2}{ }^{*}, \mathrm{~m},\{37\}, \exp 1.08 \mathrm{H}\right.$, th $\left.1.00 \mathrm{H}\right) ; 3.50-3.44\left(\mathrm{Ar}-\mathrm{O}-\mathrm{CH}_{2}{ }^{*}\right.$, $\mathrm{m},\{38\}, \exp 0.70 \mathrm{H}$, th $1.00 \mathrm{H}) ; 3.39-3.35\left(\mathrm{Ar}-\mathrm{O}-\mathrm{CH}_{2}{ }^{*}, \mathrm{~m},\{38\}, \exp 0.27 \mathrm{H}\right.$, th $\left.1.00 \mathrm{H}\right) ; 2.75$ $\left(\mathrm{O}=\mathrm{C}-\mathrm{CH}_{2}-\mathrm{CH}_{2}{ }^{*}, \mathrm{t},\{23\}, \exp 1.95 \mathrm{H}\right.$, th $\left.2.00 \mathrm{H}\right) ; 2.62\left(\mathrm{O}=\mathrm{C}_{-} \mathrm{CH}_{2}{ }^{*}, \mathrm{t},\{22\}\right.$, $\exp 1.55 \mathrm{H}$, th $\left.2.00 \mathrm{H}\right)$; 2.55-2.51 (O=C- $\mathrm{CH}_{2}-\mathrm{CH}_{2}{ }^{* *}, \mathrm{~m},\{41\}, \exp 1.20 \mathrm{H}$, th $\left.2.00 \mathrm{H}\right) ; 2.24-2.02\left(\mathrm{O}=\mathrm{C}-\mathrm{CH}_{2}{ }^{* *}, \mathrm{~m},\{40\}\right.$, $\exp 2.13 \mathrm{H}$, th $2.00 \mathrm{H}) \mathrm{ppm}$.

${ }^{31} \mathrm{P}$ NMR (243 MHz, DMSO-d 6 , $\left.298 \mathrm{~K}\right) \delta=19.80$ (s) ppm.

MS (ESI) $m / z$, [M+H] $]^{+}$calculated for $\mathrm{C}_{54} \mathrm{H}_{53} \mathrm{~N}_{2} \mathrm{O}_{12} \mathrm{P}^{+}$, 951.32524; found, 951,32428.

\subsection{Equipment and Characterization}

An Equinox 55 ATR spectrometer (Bruker, Bremen, Germany) was used to conduct the Fourier transform infrared spectra in attenuated total reflection (ATR) mode using a diamond crystal. The sample were recorded with 32 scans and a resolution of $4 \mathrm{~cm}^{-1}$ in a range between $500-4000 \mathrm{~cm}^{-1}$.

${ }^{1} \mathrm{H}-\mathrm{NMR}$ spectra were recorded on an AVANCE NEO $600 \mathrm{MHz}-$ Spectrometer (Bruker, Bremen, Germany) with DMSO- $\mathrm{d}_{6}$ as solvent at $20{ }^{\circ} \mathrm{C} .{ }^{13} \mathrm{C}$ NMR and ${ }^{31} \mathrm{P}$ NMR spectra were recorded using the same spectrometer with a frequency of $150 \mathrm{MHz}$ and $243 \mathrm{MHz}$, respectively. The chemical shifts were reported in parts per million (ppm) and referred to residual protons in the $\mathrm{DMSO}_{-} \mathrm{d}_{6}$ at $2.50 \mathrm{ppm}$. 
DSC measurements were performed using a Discovery DSC (TA Instruments, Hüllhorst, Germany) with $10 \mathrm{~K} / \mathrm{min}$ in a range from $0{ }^{\circ} \mathrm{C}$ to $300{ }^{\circ} \mathrm{C}$ on a specimen scale of 1-2 mg under $\mathrm{N}_{2}$ atmosphere. All samples were measured 3 times and the average was taken for evaluation.

DMA experiments were performed using a DMA Q800 (TA Instruments, Hüllhorst, Germany). Thermo-mechanical properties were determined in a temperature range from $0{ }^{\circ} \mathrm{C}$ to $250{ }^{\circ} \mathrm{C}$ with a heating rate of $2 \mathrm{~K} / \mathrm{min}$ with a frequency of $1 \mathrm{~Hz}$ in a single cantilever bending mode and test specimen of $40 \times 10 \times 4 \mathrm{~mm}^{3} . T_{\mathrm{g}}$ was determined by the maximum of $\tan (\delta)$.

TGA measurements were carried out with a Q5000 (TA Instruments, Hüllhorst, Germany) with a temperature range from $25{ }^{\circ} \mathrm{C}$ to $800{ }^{\circ} \mathrm{C}$ and a heating rate of $10 \mathrm{~K} / \mathrm{min}$ under ambient and nitrogen atmosphere; 2, 5, 20 and $40 \mathrm{~K} / \mathrm{min}$ were additional heating rates for samples under nitrogen atmosphere.

UL94 vertical burning tests were performed according to DIN EN 60695-11-10 with specimen dimensions of $125 \times 13 \times 4 \mathrm{~mm}^{3}$ and ground edges.

LOI experiments were performed according to EN ISO 4589-2 with specimen type 1, dimensions of $100 \times 10 \times 4 \mathrm{~mm}$ and ground edges with an LOI apparatus (Fire Testing Technology, East Grinstead, UK).

Mass spectrometry (MS) analysis was conducted on a Bruker Impact II (Bruker, Bremen, Germany) mass spectrometer using electrospray ionization with $3 \mu \mathrm{L} / \mathrm{min}$ in DCM/Methanol 1/10 v/v.

Rheological measurements were recorded using an Anton Paar Physica MCR 302 rheometer equipped with a CTD 450 temperature control device. Small quantities of the samples were loaded in a parallel plate-plate geometry $(\phi=25 \mathrm{~mm})$. The polymerization measurements were recorded in the oscillation mode at a frequency of $1 \mathrm{~Hz}$ and a controlled strain of $0.1 \%$. Heating ramps of $2 \mathrm{~K} / \mathrm{min}$ were applied to reach a temperature of $225^{\circ} \mathrm{C}$. The sample deformation was ramped linearly from $1 \%$ to $0.2 \%$ to remain within the instrument's limitation and to maintain a linear viscoelastic behavior as the moduli $\left(\mathrm{G}^{\prime}\right.$ storage modulus, $G^{\prime \prime}$ loss modulus) increase by several orders of magnitude upon curing. The gap between the plates was maintained at $0.5 \mathrm{~mm}$ during all the experiments.

The curing was performed with different parameters for the benzoxazines. DOPO-PAfa was heated up to $105^{\circ} \mathrm{C}$, degassed and poured into a metal mold with the dimension $170 \times 130 \times 4 \mathrm{~mm}^{3}$. The melt was degassed for a second time before polymerizing with the following program $2 \mathrm{~h}$ at $170{ }^{\circ} \mathrm{C}$ and $2 \mathrm{~h}$ at $180^{\circ} \mathrm{C}$. BF-a was heated to $140{ }^{\circ} \mathrm{C}$ and $\mathrm{p}$ PEG400-PA-fa to $100^{\circ} \mathrm{C}$ before transfer to the metal mold. After curing and demolding the specimens were cut according to DMA, LOI and UL94 test dimensions.

\section{Results}

The following paragraphs describe the synthesis and analysis of the bisbenzoxazine DOPO-PA-fa (Scheme 1). The direct use of DOPO-HQ for the benzoxazine synthesis is not possible due to the high degree of substitution and the resulting steric hindrance. Furthermore, the reduced reactivity of its hydroxyl groups is a challenge in the esterification step with PA. Therefore, the chain extension with ethylene carbonate was performed to promote the esterification with PA leading to DOPO-PA.

The esterification reaction of DOPO-OH and PA was performed in the presence of $p$-TSA (Scheme 2). The structural features of DOPO-PA were determined by ${ }^{1} \mathrm{H}$ NMR, FTIR and MS. ${ }^{1} \mathrm{H}$ NMR spectrum of DOPO-PA proved the full conversion of DOPO$\mathrm{OH}$ as attested by the disappearance of the aliphatic hydroxyl groups at $4.46 \mathrm{ppm}$ and $4.86 \mathrm{ppm}$ (Figure 1). The signal at $9.17 \mathrm{ppm}$ was assigned to the phenolic hydroxyl group. Furthermore, signals at $4.21 \mathrm{ppm}$ and $4.35 \mathrm{ppm}$ corresponding to a $\mathrm{CH}_{2}-\mathrm{O}-\mathrm{CO}$ binding motif confirmed the ester formation. 


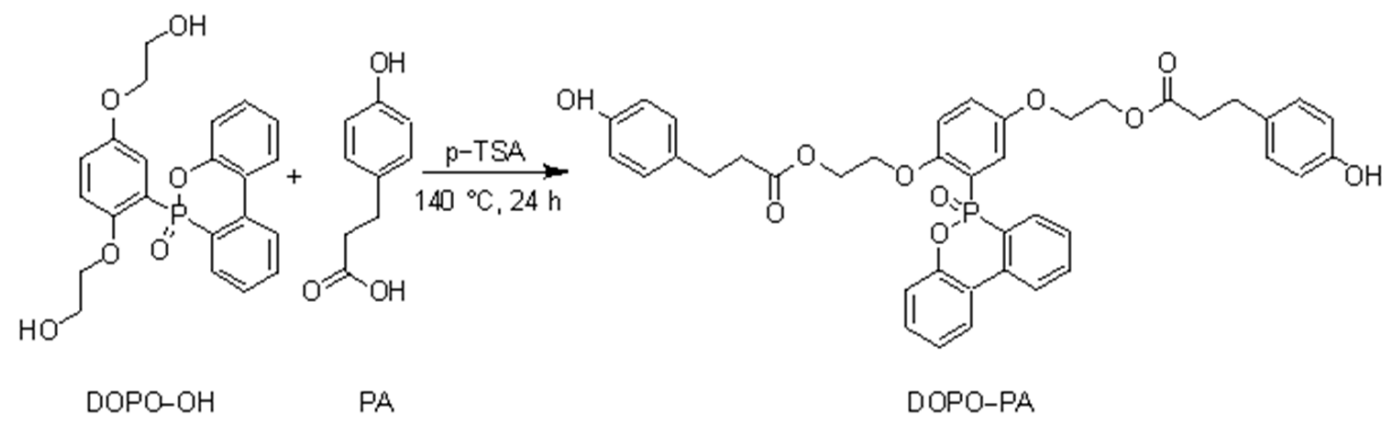

Scheme 2. Reaction scheme for the synthesis of the benzoxazine precursor DOPO-PA.

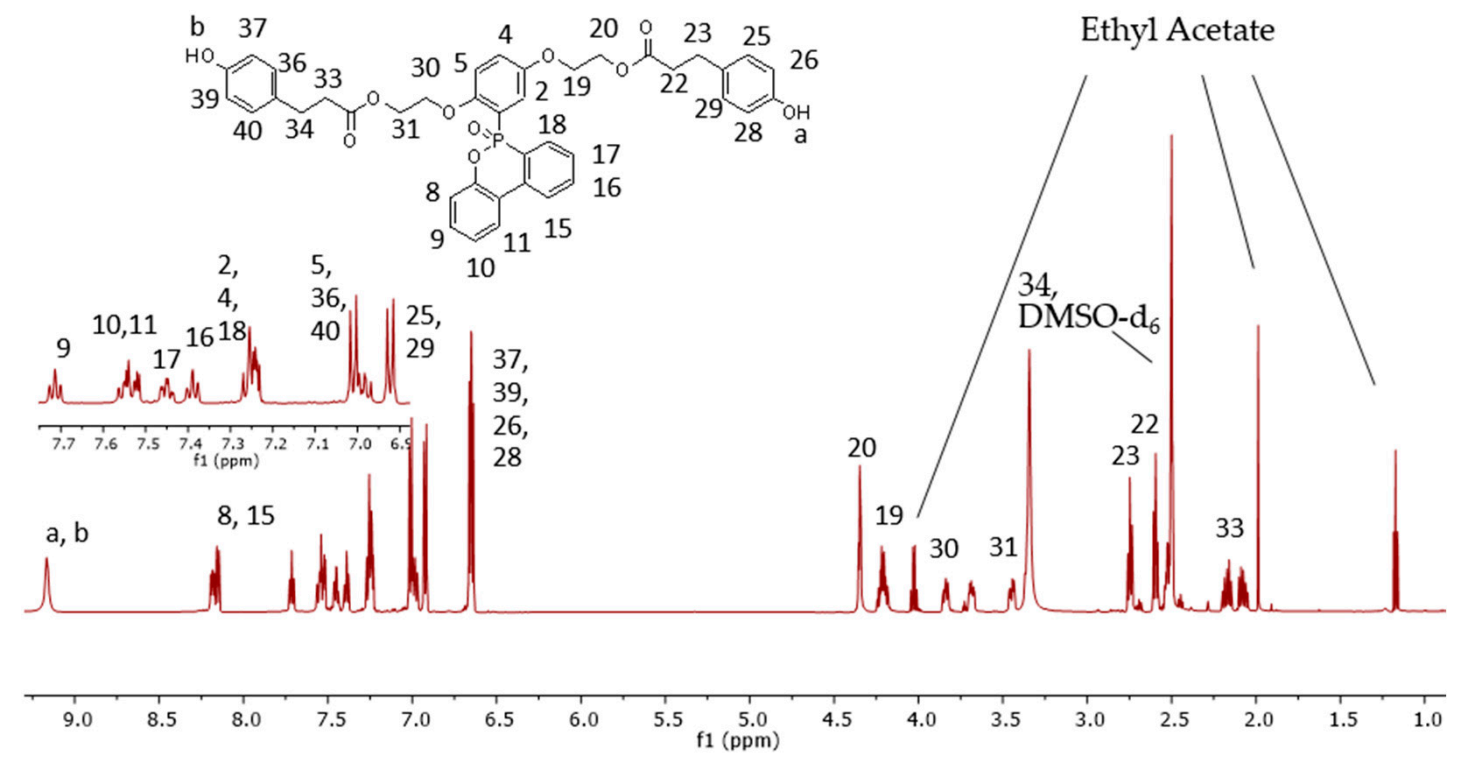

Figure 1. ${ }^{1} \mathrm{H}$ NMR spectrum of DOPO-PA (in DMSO-d $\mathrm{d}_{6}$ ).

The different chemical shifts for methylene protons 19 and 20 in comparison with 30 and 31 originated from the asymmetric substitution of the aromatic ring as previously reported by Zhang et al. [27] and Pospiech et al. [25,35]. Accordingly, it can be assumed that this effect is responsible for the different chemical shifts in case of the ester $\alpha$-methylene protons 22 and 33 and the $\beta$ protons 23 and 34. This different chemical shift is reported for polyesters containing DOPO-OH with different aliphatic or aromatic acids showing a regioregularity effect that can only result from non-equal ester $\alpha$-methylene protons $[25,35]$.

Additionally, the sterical effect of the bulky asymmetric DOPO group leads to magnetically deviating protons at position 30, resulting in a further splitting of the signal. As the planar DOPO group is asymmetric and the phenyl rings prevent free rotation, intraand intermolecular interactions between the ester bonds and the double bond $\mathrm{P}=\mathrm{O}$ (out of plane) induce a spatial conformation.

The ester formation was confirmed by FTIR (Figure 2). A shift of the characteristic peak of the carboxyl group from $1696 \mathrm{~cm}^{-1}$ to $1710 \mathrm{~cm}^{-1}$ and $1723 \mathrm{~cm}^{-1}$ was observed proving the formation of ester linkages. It is further confirmed by the disappearance of the $\mathrm{C}-\mathrm{O}-\mathrm{H}$ stretching signal of DOPO-OH at $1030 \mathrm{~cm}^{-1}$, indicating the full consumption of the aliphatic hydroxyl groups. 


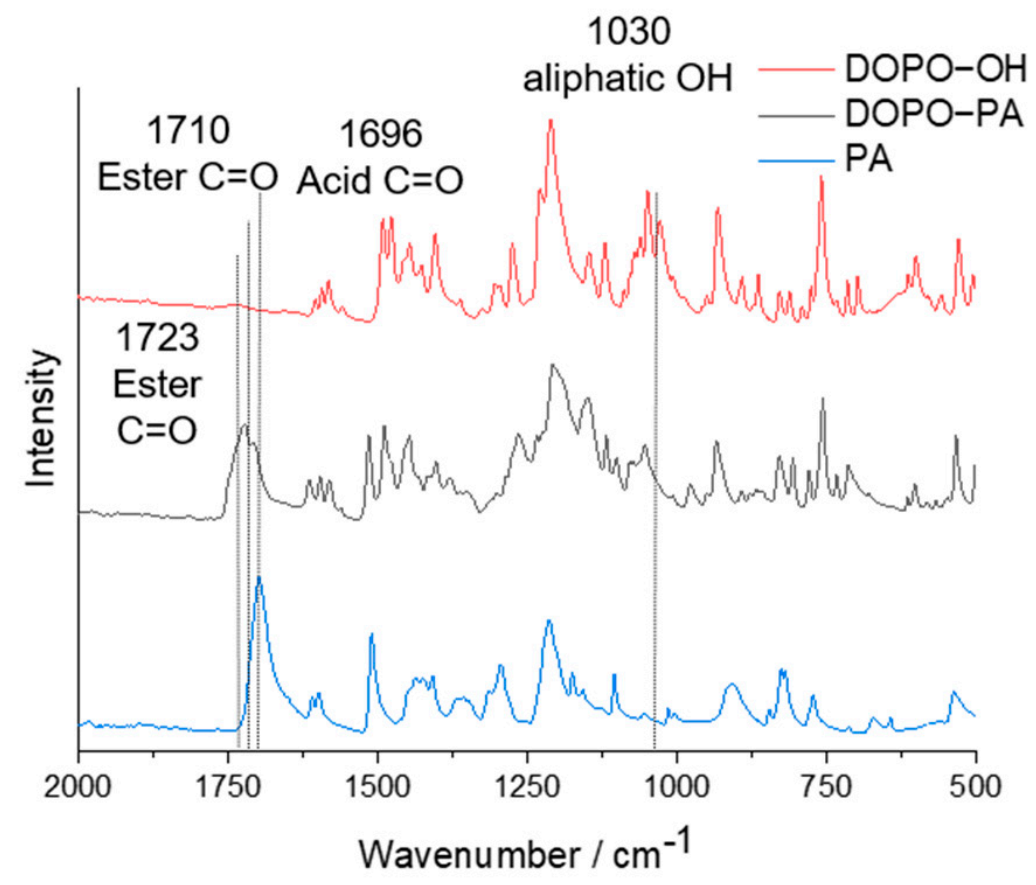

Figure 2. FTIR spectra of DOPO-OH, DOPO-PA and PA.

3.1. Synthesis and Characterization of Benzoxazine Monomer Containing DOPO-PA (DOPO-PA-fa)

DOPO-PA was reacted in chloroform with furfurylamine and paraformaldehyde to yield DOPO-PA-fa (Scheme 3).

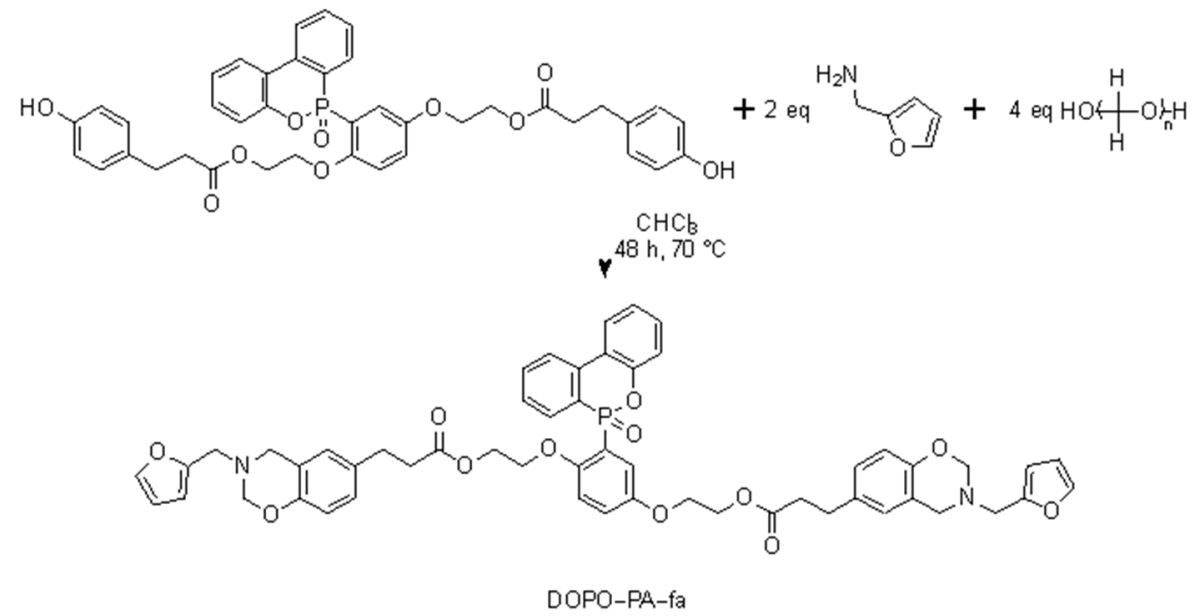

Scheme 3. General reaction scheme for the synthesis of DOPO-PA-fa.

The benzoxazine ring formation was observed by FTIR (Figure 3). The signal at $912 \mathrm{~cm}^{-1}$ was assigned to the ring vibration of benzoxazine rings. The signal at $731 \mathrm{~cm}^{-1}$ corresponds to a mono substituted furan ring. Furthermore, the $\mathrm{O}-\mathrm{H}$ stretching band at $3333 \mathrm{~cm}^{-1}$ was reduced significantly, but it was still present, presumably due to an incomplete benzoxazine formation. 


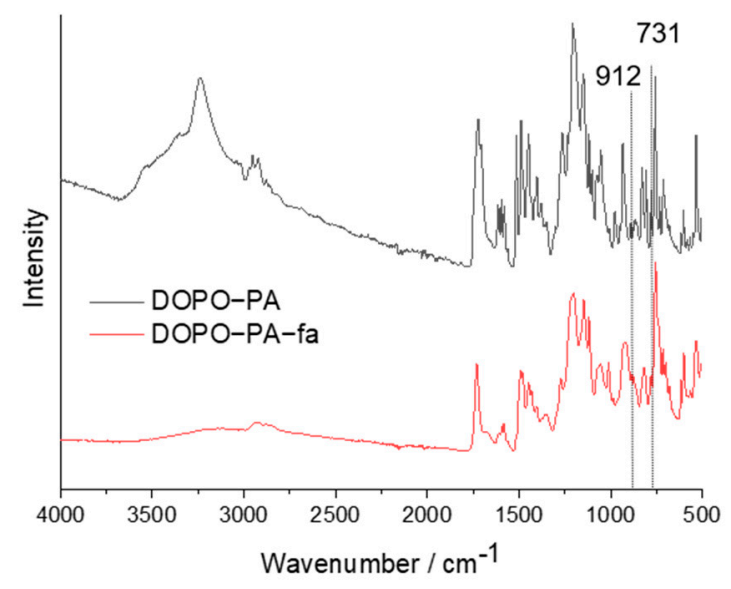

Figure 3. FTIR spectra of DOPO-PA and DOPO-PA-fa.

The benzoxazine ring formation was also confirmed by ${ }^{1} \mathrm{H}$ NMR (Figure 4). The signals at $4.76 \mathrm{ppm}$ and $3.84 \mathrm{ppm}$ correspond to the protons of $\mathrm{O}-\mathrm{CH}_{2}-\mathrm{N}$ and $\mathrm{Ar}-\mathrm{CH}_{2}-\mathrm{O}$, respectively. Furthermore, the protons of the furan ring are identified by the signals at 6.86 , 6.41 and $6.29 \mathrm{ppm}$ and the protons of the furfurylamine methylene linkage at $3.80 \mathrm{ppm}$. As in the case of double bond in DOPO-PA, the $\mathrm{P}=\mathrm{O}$ bond as well as the lone pair of the tertiary amine (also out of plane) can induce a preferential spatial conformation. Therefore, each type of end-chain oxazine ring methylene peak (30 and 48 or 31 and 49) deviate in the chemical shift, as they are not equivalent. A small residual phenolic hydroxyl group signal at $9.17 \mathrm{ppm}$ indicates that the benzoxazine formation was incomplete, in line with FTIR characterizations. The signal of the $\mathrm{O}-\mathrm{CH}_{2}-\mathrm{N}$ and the aromatic signal at $7.71 \mathrm{ppm}$ were set in relation to each other to determine the degree of benzoxazine ring formation. The values of the integration were 2.6 and 1.00 , indicating that $65 \%$ of the benzoxazine rings are closed.
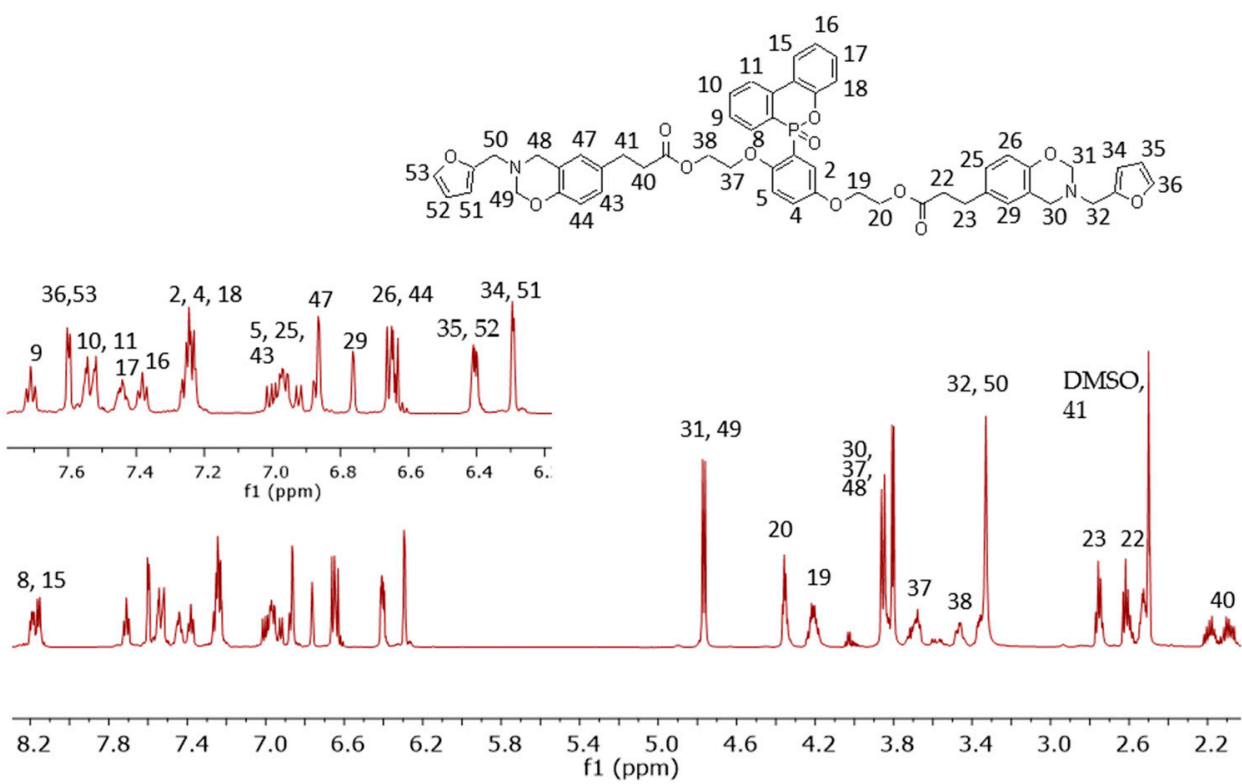

Figure 4. ${ }^{1} \mathrm{H}$ NMR spectrum in (DMSO- $\mathrm{d}_{6}$ ) of DOPO-PA-fa.

\subsection{Thermal Analysis of DOPO-PA-fa}

The polymerization of the novel bio-based DOPO-PA-fa was determined by DSC analysis and compared with a conventional bisphenol $\mathrm{F}$ and aniline based benzoxazine monomer (BF-a) and a bisbenzoxazine, based on a flexible PEG400 linker (PEG400-PA-fa), as described earlier (Figure 5) [14]. The molecular mass for the spacer group of DOPO-PA- 
fa and PEG400-PA-fa is similar with approx. $420 \mathrm{~g} / \mathrm{mol}$. It is worth mentioning that this reference was selected due to the similar molecular weight of the spacer and their synthesis approach. As the linker of the studied molecule and the reference solely differ in the DOPO functionality, it was expected that the structure of the polymers from DOPO-PA-fa and PEG400-PA-fa would help to identify the contribution of the DOPO moiety.<smiles>O=C(CCc1ccc2c(c1)CN(Cc1ccco1)CO2)OCCOC(=O)CCc1ccc2c(c1)CN(Cc1ccco1)CO2</smiles>

Figure 5. Chemical structure of the reference PEG400-PA-fa [14].

The DSC analysis of DOPO-PA-fa reveals an exothermic signal in the range of $180-260^{\circ} \mathrm{C}$, assigned to the benzoxazine ring-opening polymerization (Figure 6 and Table 1). The temperature onset ( $T_{\text {onset }}$ ) of DOPO-PA-fa at $208{ }^{\circ} \mathrm{C}$ is similar to the $T_{\text {onset }}$ of BF-a $\left(216^{\circ} \mathrm{C}\right)$ but higher to the $T_{\text {onset }}$ of PEG400-PA-fa $\left(177^{\circ} \mathrm{C}\right)$. The $T_{\text {onset }}$ of DOPO-PA-fa is in the range of previously reported benzoxazine containing DOPO [23,27]. The lower $T_{\text {onset }}$ may, presumably, be due to the residual phenolic impurities observed by FTIR and NMR.

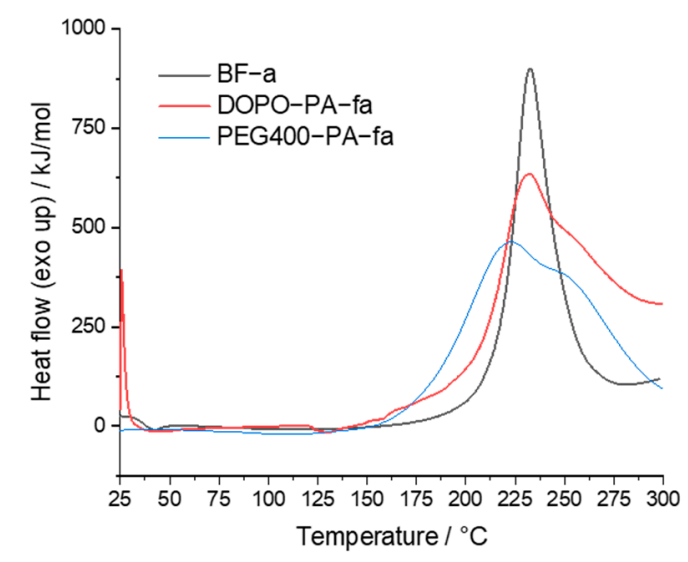

Figure 6. DSC thermograms of BF-a, DOPO-PA-fa and PEG400-PA-fa.

Table 1. DSC analysis of DOPO-PA-fa, BF-a and PEG400-PA-fa.

\begin{tabular}{ccccc}
\hline Formulation & $\boldsymbol{T}_{\text {onset }}\left[{ }^{\circ} \mathrm{C}\right]$ & $\boldsymbol{T}_{\text {peak }}\left[{ }^{\circ} \mathbf{C}\right]$ & $\Delta \boldsymbol{H}[\mathbf{J} / \mathrm{g}]$ & $\Delta \boldsymbol{H}[\mathrm{kJ} / \mathbf{m o l}]$ \\
\hline BF-a & 213 & 236 & 293 & 127 \\
DOPO-PA-fa & 208 & 232 & 133 & 126 \\
PEG400-PA-fa & 177 & 217 & 118 & 112 \\
\hline
\end{tabular}

The polymerization enthalpies of BF-a and DOPO-PA-fa are in the same range: 112 and $127 \mathrm{~kJ} / \mathrm{mol}$, respectively (Table 1, columns 4 and 5). However, their polymerization profiles differ by the presence of a shoulder for DOPO-PA-fa in the range of $240-250{ }^{\circ} \mathrm{C}$, which is expected to be due to the involvement of the fa group during the polymerization process as shown in previous publications $[5,30]$.

A potential degradation influencing the polymerization enthalpy was excluded as the initial degradation of DOPO-PA-fa at $5 \%$ weight loss was occurring at $214{ }^{\circ} \mathrm{C}$ (Figure S5).

Rheology was performed to investigate the polymerization progress (Figure 7). The recorded rheogram shows the evolution of the complex viscosity with increasing temperature. As mentioned before, PEG400-PA-fa starts to polymerize at a lower temperature 
as an increase in the complex viscosity was observed in the range of $175-185^{\circ} \mathrm{C}$, while DOPO-PA-fa and BF-a start to polymerize between $200-205^{\circ} \mathrm{C}$.

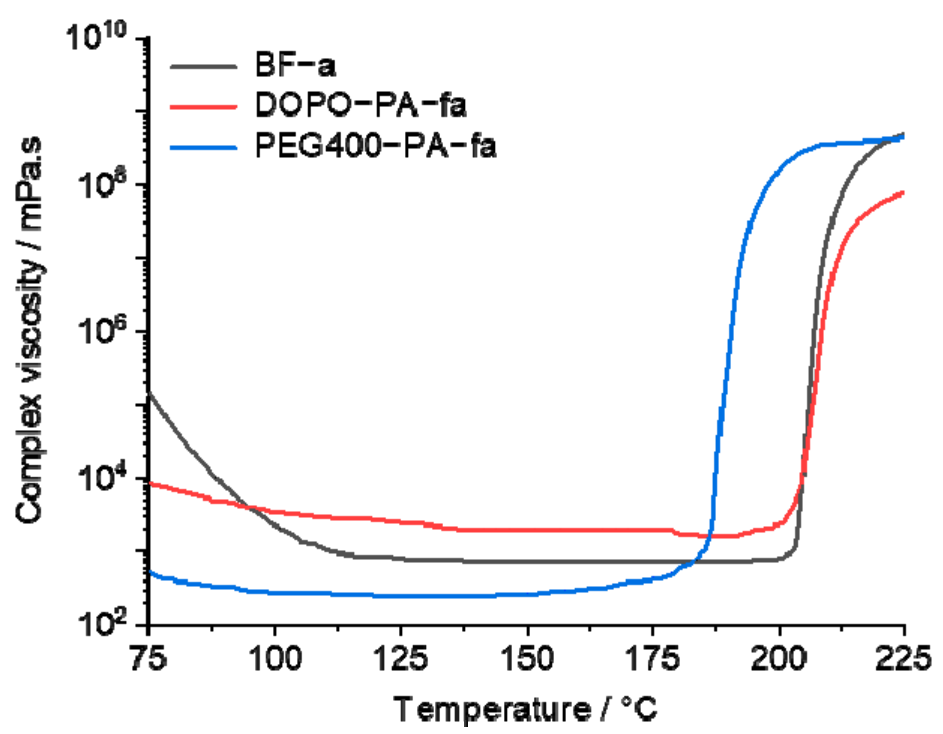

Figure 7. Evolution of the complex viscosity of each benzoxazine monomer as a function of the temperature.

In summary, the benzoxazine monomer containing DOPO seems to delay the polymerization of the benzoxazine monomer. However, in spite of this delay, the range of the kinetics of polymerization is similar to traditional and commercial BF-a.

\subsection{Thermo-Mechanical Properties of the Resulting Bisbenzoxazine Polymers}

The glass transition temperature $\left(T_{\mathrm{g}}\right)$ of the polymer pDOPO-PA-fa was measured at $150^{\circ} \mathrm{C}$ (Figure S6 and Table 2), lower than the $T_{\mathrm{g}}$ of pBF-a $\left(175^{\circ} \mathrm{C}\right)$. It can be explained by the lower number of benzoxazine groups per grams of pDOPO-PA-fa compared with pBF-a. However, the rigid structure shows a beneficial effect on $T_{\mathrm{g}}$ when comparing with pPEG400-PA-fa $\left(T_{\mathrm{g}}=26^{\circ} \mathrm{C}\right)$. The storage modulus of pDOPO-PA-fa $(2.7 \mathrm{GPa})$ at $20^{\circ} \mathrm{C}$ is higher as for pPEG400-PA-fa $\left(\mathrm{E}_{0}=1.2 \mathrm{GPa}\right)$ as it already reached its $T_{\mathrm{g}}$ (Figure 8$)$. While pDOPO-PA-fa and pPEG400-PA-fa contained a similar weight content of benzoxazine groups with 55\% the bulkier DOPO-spacer group is improving the mechanical properties in comparison with the aliphatic PEG units. Thus, the DOPO linker increases significantly mechanical and thermal properties of the bio-based bisbenzoxazine. However, the storage modulus is slightly lower in comparison to pBF-a $(3.0 \mathrm{GPa})$ with the highest benzoxazine proportion.

Table 2. Dynamical mechanical properties of pBF-a, pDOPO-PA-fa and pPEG400-PA-fa.

\begin{tabular}{|c|c|c|c|}
\hline Monomer & $E_{20}^{\prime}[\mathrm{GPa}]^{\mathrm{a}}$ & $E_{100}^{\prime}[\mathrm{GPa}]^{b}$ & $T_{\mathrm{g}}\left[{ }^{\circ} \mathrm{C}\right]^{\mathrm{c}}$ \\
\hline pBF-a & 3.0 & 2.8 & 175 \\
\hline pDOPO-PA-fa & 2.7 & 2.3 & 150 \\
\hline pPEG400-PA-fa & 0.3 & $1.2 *$ & 26 \\
\hline
\end{tabular}

a $E_{20}^{\prime}$ was determined at $20{ }^{\circ} \mathrm{C}^{\mathrm{b}} \mathrm{E}^{\prime}$ was determined at $100{ }^{\circ} \mathrm{C} ;{ }^{*}$ measured at $0{ }^{\circ} \mathrm{C} ;{ }^{\mathrm{c}} \mathrm{T}^{\mathrm{g}}$ was determined by the maximum of $\tan (\delta)$. 


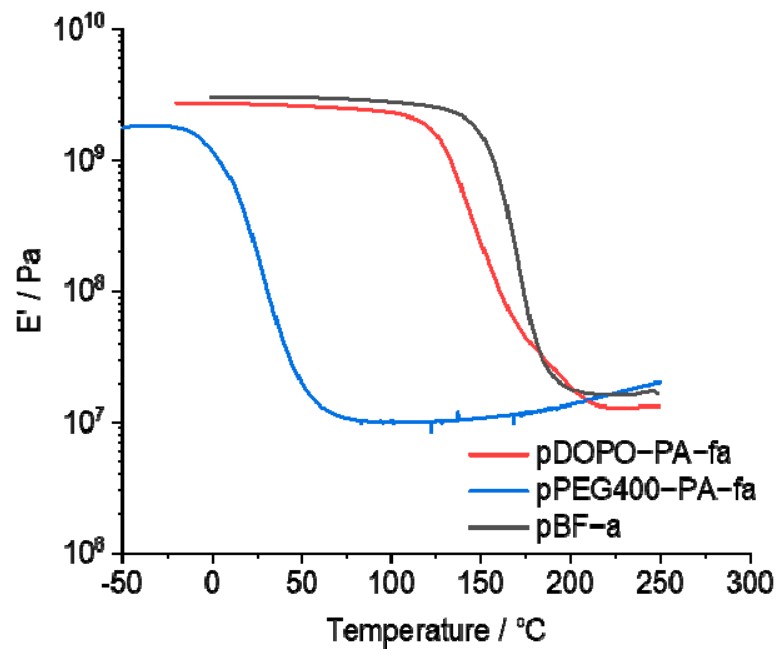

Figure 8. DMA results of pBF-a, pDOPO-PA-fa and pPEG400-PA-fa.

\subsection{Thermal Stability and Thermal Degradation Kinetics}

The three polymers pBF-a, pDOPO-PA-fa and pPEG400-PA-fa all have a similar degradation profile under inert atmosphere (Figure 9a). The initial degradation temperature was $314{ }^{\circ} \mathrm{C}$ at a mass loss of $5 \mathrm{wt} \%\left(T_{5 \%}\right)$ for pDOPO-PA-fa and pBF-a. pPEG400-PA-fa had a slightly reduced initial stability with $T_{5 \%}=291{ }^{\circ} \mathrm{C}$. The evaluated temperature at $20 \mathrm{wt} \%$ mass loss showed that pDOPO-PA-fa and pPEG400-PA-fa show a comparable degradation temperature at $390{ }^{\circ} \mathrm{C}$, whereas pBF-a is slightly more stable with $T_{20} \%=400{ }^{\circ} \mathrm{C}$. While pPEG400-PA-fa achieved a char yield of 32\%, both pDOPO-PA-fa and pBF-a achieved a char yield of $44 \%$. The incorporation of DOPO in the linker structure of the bisbenzoxazine has a beneficial effect on the thermal stability by significantly increasing the char yield in comparison with pPEG400-PA-fa.
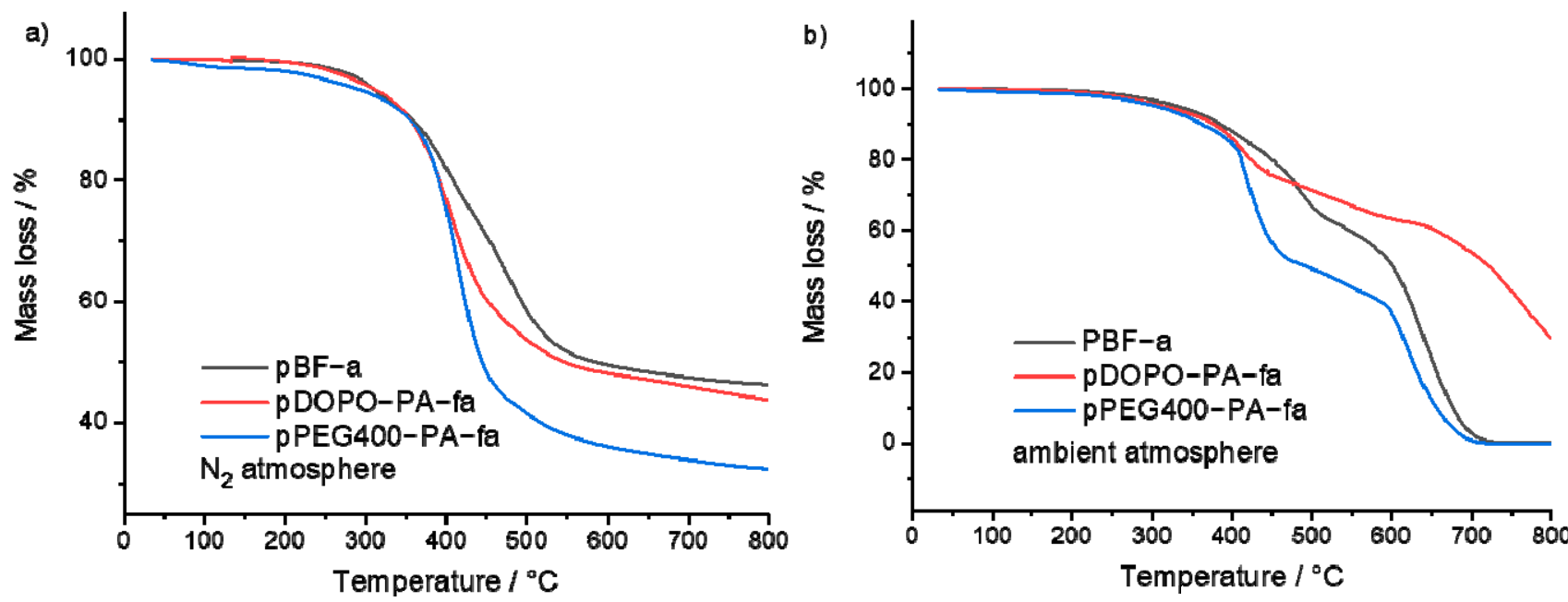

Figure 9. Thermogravimetric analysis of pBF-a, pDOPO-PA-fa and pPEG400-PA-fa under $\mathrm{N}_{2}(\mathbf{a})$ and ambient atmosphere (b).

In thermo-oxidative conditions, the polymers showed only slight differences for the initial degradation stability with $309^{\circ} \mathrm{C}, 317^{\circ} \mathrm{C}$ and $328^{\circ} \mathrm{C}$ for pPEG400-PA-fa, pDOPOPA-fa and pBF-a, respectively. However, at temperatures above $500{ }^{\circ} \mathrm{C}$ pDOPO-PA-fa was more stable and reached a char yield of $30 \%$ at $800{ }^{\circ} \mathrm{C}$ in contrast to no residual mass formation for pBF-a and pPEG400-PA-fa. This effect shows the advantage of the DOPO presence in the molecular structure as it shows a significant effect on the char yield formation at $800^{\circ} \mathrm{C}$ under ambient atmosphere. 
Aside studying the degradation temperatures, the activation energy $\left(E_{\mathrm{a}}\right)$ as an important kinetic parameter was derived from thermograms obtained under different heating regimes. $E_{\mathrm{a}}$ is directly related to the energetic needs for bond dissociation processes and indicates the tendency of material degradation during heating. The Flynn-Wall-Ozawa (FWO) method was used to calculate $E_{a}$ for pDOPO-PA-fa, pBF-a and pPEG400-PA-fa [36]. The FWO method is an isoconversional method that does not depend on the conversion function [37]. As long as the degradation mechanism stays the same for the investigated area, the method is not changing with different heating rates for different conversions. $E_{\mathrm{a}}$ (determined by $-0.4567 \frac{E_{a}}{R T}$ ) can be obtained from the slope of $\log _{10}(\beta)$ versus $1000 / T_{c}$ for different conversions obtained from TGA with different heating rates (Figure 10 and Figure S10). The FWO method can be expressed by the following Equation (1):

$$
\log _{10}(\beta)=\log _{10}\left(\frac{A E_{a}}{R(\alpha)}\right)-2.315-0.4567 \frac{E_{a}}{R T_{c}}
$$

where $\beta$ is the heating rate, $T_{c}$ is the temperature at a conversion $\alpha$, with $A$ as frequency factor, $R$ as gas constant and $E_{\mathrm{a}}$ as activation energy for the thermal degradation.

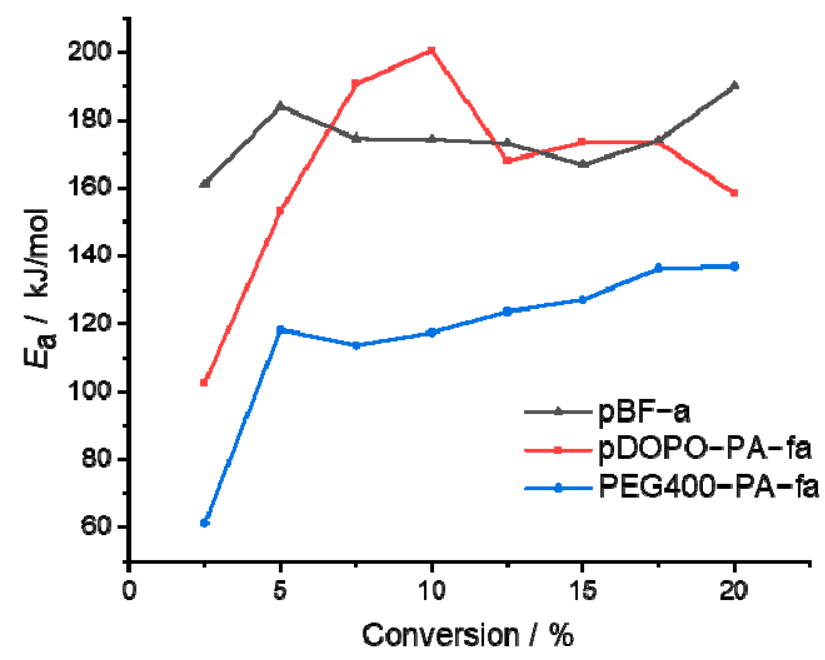

Figure 10. The degradation activation energy as a function of the degradation conversion of pDOPOPA-fa, pBF-a and pPEG400-PA-fa, as determined by the Flynn-Wall-Ozawa equation.

The study was performed by using different heating rates $2,5,10,20$ and $40 \mathrm{~K} / \mathrm{min}$ for pDOPO-PA-fa, pBF-a and pPEG400-PA-fa (Figure S7). The investigated conversions $(\alpha)$ for each heating rate and polymer were $2.5,5,7.5,1012.5,15,17.5$ and $20 \%$.

For all studied compounds, a higher $E_{\mathrm{a}}$ was determined with increasing conversion. Thus, a higher energy is needed for further degradation. For a conversion of $20 \% E_{\mathrm{a}}$ proved to be higher for the DOPO-containing pDOPO-PA-fa $\left(E_{\mathrm{a}}=158 \mathrm{~kJ} / \mathrm{mol}\right)$ in comparison to pPEG400-PA-fa $\left(E_{\mathrm{a}}=136 \mathrm{~kJ} / \mathrm{mol}\right)$. The reference pBF-a $\left(E_{\mathrm{a}}=190 \mathrm{~kJ} / \mathrm{mol}\right)$ needs more energy as it is slightly more stable than pDOPO-PA-fa. However, at a conversion of $10 \%$ the needed $E_{\mathrm{a}}$ for pDOPO-PA-fa $\left(E_{\mathrm{a}}=200 \mathrm{~kJ} / \mathrm{mol}\right)$ exceeds those of pBF-a $\left(E_{\mathrm{a}}=172 \mathrm{~kJ} / \mathrm{mol}\right)$.

\subsection{Investigations on the Reaction against Small Flames}

UL94 and LOI tests were conducted to investigate the reaction of each polymer against small flames (Table 3). According to the literature, pBF-a is achieving a V-1 rating with a total burning time of $24 \mathrm{~s}$. pPEG400-PA-fa failed the test as it was burning longer than $60 \mathrm{~s}$. This result is explained by the PEG backbone that widens the network and the less stable oxyethylene units. pDOPO-PA-fa achieved a V-0 rating with $1 \mathrm{~s}$ of total burning time, proving the efficiency of the incorporated DOPO spacer group. 
Table 3. Results of the UL94 and LOI burning tests for pBF-a, pDOPO-PA-fa and pPEG400-PA-fa.

\begin{tabular}{ccccc}
\hline Additive & Pwt $\%$ & $\begin{array}{c}\text { Total Burning Time } \\
\text { [s] }\end{array}$ & UL-94 Grade & LOI [\%] \\
\hline pBF-a & 0 & $23.8 \pm 4.4$ & $\mathrm{~V}-1$ & $26.1 \pm 0.19$ \\
pDOPO-PA-faP & 3.3 & $0.9 \pm 0.5$ & $\mathrm{~V}-0$ & $35.0 \pm 0.27$ \\
pPEG400-PA-fa & & $>180$ & n.b. & $21.5 \pm 0.11$ \\
pBF-a/DOPO-PA-fa/ & 0.21 & & & $27.9 \pm 0.17$ \\
pBF-a/ DOPO-HQ & 0.21 & & & $28.25 \pm 0.15$ \\
$\begin{array}{c}\text { pPEG400-PA- } \\
\text { fa/DOPO-PA-fa/ }\end{array}$ & 0.21 & & & $23.6 \pm 0.15$ \\
pPEG400-PA- & 0.21 & & & \\
fa/DOPO-HQ & & & & \\
\hline
\end{tabular}

As expected from the UL94 tests pPEG400-PA-fa achieved the lowest oxygen index $(O I)$ with $21.5 \%$. pBF-a achieved an OI of $26 \%$ and the pDOPO-PA-fa an OI of $35 \%$. The significant improvement is according to the literature as a DOPO-, aniline- and phenolbased monomer with a phosphorous loading of $7.8 \mathrm{wt} \%$ achieved an OI of $40 \%$ [31].

Finally, the efficiency of DOPO-PA-fa to act as a flame retarding agent for other polymers was tested. For that purpose, it was blended with BF-a or PEG400-PA-fa (7 wt\% of DOPO-PA-fa leading a phosphorous loading of $0.21 \mathrm{wt} \%$ ) and compared to blends of BFa and PEG400-PA-fa with the reactive additive DOPO-HQ resulting the same phosphorous loading of $0.21 \mathrm{wt} \%$. Polymerized blends of DOPO-PA-fa and BF-a achieved an OI of $28 \%$, while blends with PEG400-PA-fa an OI of $23.6 \%$. Both OI values were increased by $2 \%$, which is similar for the reactive additive as well $(28.2 \%$ for $\mathrm{pBF}-\mathrm{a}$ and $23.6 \%$ for pPEG400-PA-fa). This approach is promising as it shows a similar effectivity as the neat DOPO-HQ without being limited in regards to the loading.

\section{Conclusions}

This study describes the incorporation of a DOPO spacer group into bio-based benzoxazine monomer. DOPO-HQ was reacted with ethylene carbonate to promote its reactivity toward a solvent-free esterification with PA, to obtain a diphenol end-capped DOPO molecule. This precursor was reacted with furfurylamine and paraformaldehyde, leading to the benzoxazine monomer DOPO-PA-fa. The successful 4-step synthesis pathway was verified by NMR, IR and MS analysis.

The polymerization behavior and thermo-mechanical properties of the corresponding polymer were analyzed by DSC, DMA and rheological analysis and compared to BF-a and PEG400-PA-fa. Results showed that for DOPO-PA-fa, the polymerization starts at around $200{ }^{\circ} \mathrm{C}$, alike to BF-a. Its $T_{\mathrm{g}}\left(150^{\circ} \mathrm{C}\right)$ is lower than for rigid pBF-a $\left(175^{\circ} \mathrm{C}\right)$ but significantly higher than for the flexible pPEG400-PA-fa $\left(20^{\circ} \mathrm{C}\right)$.

The thermal stability and reaction tests against small flames showed the improved stability of pDOPO-PA-fa. While the thermal stability for the partly bio-based pDOPOPA-fa under $\mathrm{N}_{2}$ atmosphere is already comparable to those of pBF-a, under ambient atmosphere it shows an increased stability with a char yield of $30 \%$ at $800{ }^{\circ} \mathrm{C}$, whereas those for pBF-a and pPEG400-PA-fa are 0\%. During UL94 test, pDOPO-PA-fa reached a V-0 rating and an OI of 35\%. Thus, DOPO-PA-fa proved to be an interesting, partly bio-based benzoxazine monomer, with promising properties as an FR monomer for future applications.

Supplementary Materials: The following are available online at https:/ / www.mdpi.com/article/10 .3390 / polym13244330/s1, Scheme S1: Synthesis of DOPO-OH, Figure S1: ${ }^{13} \mathrm{C}$ NMR of DOPO-PA $\left(\right.$ DMSO- $\left.\mathrm{d}_{6}\right)$, Figure S2: ${ }^{31} \mathrm{P}$ NMR of DOPO-PA, Figure S3: ${ }^{13} \mathrm{C}$ NMR of DOPO-PA-fa (DMSO- $\left.\mathrm{d}_{6}\right)$, Figure S4: ${ }^{31} \mathrm{P}$ NMR of DOPO-PA-fa, Figure S5: Thermogravimetric analysis of BF-a, DOPO-PA-fa and PEG400-PA-fa monomers under $\mathrm{N}_{2}(\mathbf{a})$ and ambient atmosphere (b), Figure S6: $\operatorname{Tan}(\delta)$ results for pBFa, pDOPO-PA-fa and pPEG400-PA-fa, Figure S7: TGA thermograms of pBF-a (a), pDOPO-PA-fa (b) and pPEG400-PA-fa (c) at different heating rates (2, 5, 10, 20 and $40 \mathrm{~K} / \mathrm{min})$, Figure S8: Flynn-Wall- 
Ozawa isoconversion plot for the calculation of activation energy for pBF-a (a), pDOPO-PA-fa (b) and pPEG400-PA-fa (c).

Author Contributions: Conceptualization, T.S.H., L.P., P.V. and K.K.; methodology, T.S.H., L.P., P.V. and K.K.; validation, T.S.H., L.P., P.V. and K.K.; investigation, T.S.H., A.A.; resources, P.V., K.K.; writing-original draft preparation, T.S.H.; writing-review and editing, T.S.H., L.P., A.A., P.V. and K.K.; visualization, T.S.H.; supervision, P.V. and K.K.; project administration, P.V. and K.K.; funding acquisition, T.S.H. and K.K. All authors have read and agreed to the published version of the manuscript.

Funding: Thorben S. Haubold would like to thank Bremen IDEA-Research stays abroad funded by the Central Research Development Fund.

Institutional Review Board Statement: Not applicable.

Informed Consent Statement: Not applicable.

Data Availability Statement: Not applicable.

Conflicts of Interest: The authors declare no conflict of interest. The funders had no role in the design of the study; in the collection, analyses, or interpretation of data; in the writing of the manuscript, or in the decision to publish the results.

\section{References}

1. Ishida, H.; Low, H.Y. A Study on the Volumetric Expansion of Benzoxazine-Based Phenolic Resin. Macromolecules 1997, 30, 1099-1106. [CrossRef]

2. Shen, S.B.; Ishida, H. Development and characterization of high-performance polybenzoxazine composites. Polym. Compos. 1996, 17, 710-719. [CrossRef]

3. Wang, X.; Niu, H.; Huang, J.; Song, L.; Hu, Y. A desoxyanisoin- and furfurylamine-derived high-performance benzoxazine thermoset with high glass transition temperature and excellent anti-flammability. Polym. Degr. Stab. 2021, 189, 109604. [CrossRef]

4. Wang, C.; Sun, J.; Liu, X.; Sudo, A.; Endo, T. Synthesis and copolymerization of fully bio-based benzoxazines from guaiacol, furfurylamine and stearylamine. Green Chem. 2012, 14, 2799. [CrossRef]

5. Monisha, M.; Yadav, N.; Lochab, B. Sustainable Framework of Chitosan-Benzoxazine with Mutual Benefits: Low Curing Temperature and Improved Thermal and Mechanical Properties. ACS Sust. Chem. Eng. 2019, 7, 4473-4485. [CrossRef]

6. Liu, X.; Zhang, R.; Li, T.; Zhu, P.; Zhuang, Q. Novel Fully Biobased Benzoxazines from Rosin: Synthesis and Properties. ACS Sust. Chem. Eng. 2017, 5, 10682-10692. [CrossRef]

7. Amarnath, N.; Appavoo, D.; Lochab, B. Eco-Friendly Halogen-Free Flame Retardant Cardanol Polyphosphazene Polybenzoxazine Networks. ACS Sust. Chem. Eng. 2017, 6, 389-402. [CrossRef]

8. Van, A.; Chiou, K.; Ishida, H. Use of renewable resource vanillin for the preparation of benzoxazine resin and reactive monomeric surfactant containing oxazine ring. Polymer 2014, 55, 1443-1451. [CrossRef]

9. Yang, R.; Han, M.; Hao, B.; Zhang, K. Biobased high-performance tri-furan functional bis-benzoxazine resin derived from renewable guaiacol, furfural and furfurylamine. Eur. Polym. J. 2020, 131, 109706. [CrossRef]

10. Salum, M.L.; Iguchi, D.; Arza, C.R.; Han, L.; Ishida, H.; Froimowicz, P. Making Benzoxazines Greener: Design, Synthesis, and Polymerization of a Biobased Benzoxazine Fulfilling Two Principles of Green Chemistry. ACS Sustain. Chem. Eng. 2018, 6, 13096-13106. [CrossRef]

11. Machado, I.; Hsieh, I.; Rachita, E.; Salum, M.L.; Iguchi, D.; Pogharian, N.; Pellot, A.; Froimowicz, P.; Calado, V.; Ishida, H. A truly bio-based benzoxazine derived from three natural reactants obtained under environmentally friendly conditions and its polymer properties. Green Chem. 2021, 23, 4051-4064. [CrossRef]

12. Ganfoud, R.; Guigo, N.; Puchot, L.; Verge, P.; Sbirrazzuoli, N. Investigation on the role of the alkyl side chain of cardanol on benzoxazine polymerization and polymer properties. Eur. Polym. J. 2019, 119, 120-129. [CrossRef]

13. Puchot, L.; Verge, P.; Fouquet, T.; Vancaeyzeele, C.; Vidal, F.; Habibi, Y. Breaking the symmetry of dibenzoxazines: A paradigm to tailor the design of bio-based thermosets. Green Chem. 2016, 18, 3346-3353. [CrossRef]

14. Dumas, L.; Bonnaud, L.; Olivier, M.; Poorteman, M.; Dubois, P. Bio-based high performance thermosets: Stabilization and reinforcement of eugenol-based benzoxazine networks with BMI and CNT. Eur. Polym. J. 2015, 67, 494-502. [CrossRef]

15. Trejo-Machin, A.; Verge, P.; Puchot, L.; Quintana, R. Phloretic acid as an alternative to the phenolation of aliphatic hydroxyls for the elaboration of polybenzoxazine. Green Chem. 2017, 19, 5065-5073. [CrossRef]

16. Kirubakaran, R.; Sharma, P.; Manisekaran, A.; Bijwe, J.; Nebhani, L. Phloretic acid: A smart choice to develop low-temperature polymerizable bio-based benzoxazine thermosets. J. Therm. Anal. Calorim. 2020, 4, 21712. [CrossRef]

17. Tavernier, R.; Granado, L.; Foyer, G.; David, G.; Caillol, S. Formaldehyde-Free Polybenzoxazines for High Performance Thermosets. Macromolecules 2020, 53, 2557-2567. [CrossRef]

18. Tavernier, R.; Granado, L.; Foyer, G.; David, G.; Caillol, S. Aromatic dialdehyde-based bisbenzoxazines: The influence of relative position of oxazine rings. Polymer 2021, 216, 123270. [CrossRef] 
19. Wolter, N.; Carrillo Beber, V.; Haubold, T.; Sandinge, A.; Blomqvist, P.; Goethals, F.; van Hove, M.; Jubete, E.; Mayer, B.; Koschek, K. Effects of flame-retardant additives on the manufacturing, mechanical, and fire properties of basalt fiber-reinforced polybenzoxazine. Polym. Eng. Sci. 2021, 61, 551-561. [CrossRef]

20. Taylor, M.; Cavalli, G.; Hamerton, I. Examining the Influence of Organophosphorus Flame Retardants on the Thermal Behavior of Aromatic Polybenzoxazines. Macromol. Chem. Phys. 2019, 220, 1800282. [CrossRef]

21. Chang, C.W.; Lin, C.H.; Lin, H.T.; Huang, H.J.; Hwang, K.Y.; Tu, A.P. Development of an aromatic triamine-based flame-retardant benzoxazine and its high-performance copolybenzoxazines. Eur. Polym. J. 2009, 45, 680-689. [CrossRef]

22. Ciesielski, M.; Diederichs, J.; Döring, M.; Schäfer, A. (Eds.) Advanced Flame-Retardant Epoxy Resins for Composite Materials. In Fire and Polymers V: Advanced Flame-Retardant Epoxy Resins for Composite Materials; Oxford University Press: Oxford, UK, 2009.

23. Ho, T.-H.; Hwang, H.-J.; Shieh, J.-Y.; Chung, M.-C. Thermal, physical and flame-retardant properties of phosphorus-containing epoxy cured with cyanate ester. React. Funct. Polym. 2009, 69, 176-182. [CrossRef]

24. Liu, Y.L. Epoxy resins from novel monomers with a bis-(9,10-dihydro-9-oxa-10-oxide-10-phosphaphenanthrene-10-yl-) substituent. J. Polym. Sci. A Polym. Chem. 2002, 40, 359-368. [CrossRef]

25. Pospiech, D.; Korwitz, A.; Komber, H.; Jehnichen, D.; Häußler, L.; Scheibner, H.; Liebmann, M.; Jähnichen, K.; Voit, B. Biobased Aliphatic Polyesters with DOPO Substituents for Enhanced Flame Retardancy. Macromol. Chem. Phys. 2015, $216,1447-1461$. [CrossRef]

26. Wang, C.S.; Lin, C.H.; Chen, C.Y. Synthesis and properties of phosphorus-containing polyesters derived from 2-(6-oxido6H-dibenz[c,e][1,2]oxaphosphorin-6-yl)-1,4- hydroxyethoxy phenylene. J. Polym. Sci. A Polym. Chem. 1998, 36, 3051-3061. [CrossRef]

27. Zhang, C.; Liu, S.M.; Zhao, J.Q.; Huang, J.Y. Synthesis and properties of a modified unsaturated polyester resin with phosphoruscontaining pendant groups. Polym. Bull. 2013, 70, 1097-1111. [CrossRef]

28. Lin, C.H.; Cai, S.X.; Leu, T.S.; Hwang, T.Y.; Lee, H.H. Synthesis and properties of flame-retardant benzoxazines by three approaches. J. Polym. Sci. A Polym. Chem. 2006, 44, 3454-3468. [CrossRef]

29. Lin, C.-M.; Chen, C.-H.; Lin, C.-H.; Juang, T.-Y. High-performance bio-based benzoxazines derived from phosphinated biphenols and furfurylamine. Eur. Polym. J. 2018, 108, 48-56. [CrossRef]

30. Lin, C.H.; Lin, H.T.; Chang, S.L.; Hwang, H.J.; Hu, Y.M.; Taso, Y.R.; Su, W.C. Benzoxazines with tolyl, p-hydroxyphenyl or p-carboxyphenyl linkage and the structure-property relationship of resulting thermosets. Polymer 2009, 50, 2264-2272. [CrossRef]

31. Spontón, M.; Lligadas, G.; Ronda, J.C.; Galià, M.; Cádiz, V. Development of a DOPO-containing benzoxazine and its highperformance flame retardant copolybenzoxazines. Polym. Degr. Stab. 2009, 94, 1693-1699. [CrossRef]

32. Lin, C.H.; Lin, H.T.; Sie, J.W.; Hwang, K.Y.; Tu, A.P. Facile, one-pot synthesis of aromatic diamine-based phosphinated benzoxazines and their flame-retardant thermosets. J. Polym. Sci. A Polym. Chem. 2010, 48, 4555-4566. [CrossRef]

33. Adjaoud, A.; Dieden, R.; Verge, P. Sustainable Esterification of a Soda Lignin with Phloretic Acid. Polymers 2021, $13,637$. [CrossRef] [PubMed]

34. Adjaoud, A.; Trejo-Machin, A.; Puchot, L.; Verge, P. Polybenzoxazines: A sustainable platform for the design of fast responsive and catalyst-free vitrimers based on trans-esterification exchanges. Polym. Chem. 2021, 12, 3276-3289. [CrossRef]

35. Schwarzer, M.; Korwitz, A.; Komber, H.; Häußler, L.; Dittrich, B.; Schartel, B.; Pospiech, D. Phosphorus-Containing Polymer Flame Retardants for Aliphatic Polyesters. Macromol. Mater. Eng. 2018, 303, 1700512. [CrossRef]

36. Flynn, J.H.; Wall, L.A. General Treatment of the Thermogravimetry of Polymers. J. Res. Natl. Bur. Stand. A Phys. Chem. 1966, 70A, 487-523. [CrossRef] [PubMed]

37. Li, Y.; Qiang, Z.; Chen, X.; Ren, J. Understanding thermal decomposition kinetics of flame-retardant thermoset polylactic acid. RSC Adv. 2019, 9, 3128-3139. [CrossRef] 